DOI: $10.5862 / J P M .218 .7$

UDC 628.9

A.V. Aladov', K.A. Bulashevich', A.E. Chernyakov', S.Yu. Karpov', V.P. Valyukhov', A.L. Zakgeym

'Research and Development Center of Microelectronics and Submicron Heterostructures of RAS,

2STR Group - Soft-Impact, LTD,

${ }^{3}$ Peter the Great St. Petersburg Polytechnic University

\title{
THERMAL RESISTANSE AND NON-UNIFORM DISTRIBUTION OF ELECTROLUMINESCENCE AND TEMPERATURE IN HIGH-POWER AIGaInN LIGHT-EMITTING DIODES
}

\begin{abstract}
The paper studies current spreading, light emission, and heat transfer in highpower flip-chip light-emitting diodes (LEDs) and their effect on the chip thermal resistance by experimental and theoretical approaches. The thermal resistance was measured using two methods: by monitoring the transient response of the LED operation voltage to the temperature variation with the Transient Tester T3Ster and by temperature mapping with the use of an infrared thermal-imaging microscope. The near field of the electroluminescence intensity was recorded with an optical microscope and a CCD camera. Three-dimensional numerical simulation of the current spreading and heat transfer in the LED chip was carried out using the SimuLED package in order to interpret the obtained experimental results.

LED, CHIP, THERMAL RESISTANCE, CURRENT SPREADING, LIGHT DISTRIBUTION, ELECTROLUMINESCENCE, SIMULATION.
\end{abstract}

\section{Introduction}

There has been a general trend in recent years to increase the operating current and the chip area of the commercial high-power lightemitting diodes (LEDs) in order to provide more and more values of their output optical power. In particular, high-power CBT-140-W LEDs by Luminus, Inc. have the chip area of $14 \mathrm{~mm}^{2}$ and the operating current up to $21 \mathrm{~A}$, corresponding to the total heat dissipation power of $\sim 76 \mathrm{~W}$ and the heat release density more than $500 \mathrm{~W} / \mathrm{cm}^{2}$. In addition to the rise of the output optical power, engineers complicate the contact electrode geometry to avoid the shading effect. The flip-chip mounting on a heat sink followed by the removal of the substrate (made of sapphire as a rule) after the growth of the LED structure is widely used [1,2]. This increasing design sophistication requires paying more attention to the thermal management of LEDs operation, which should include not only evaluating the total chip thermal resistance, but thoroughly analyzing the temperature distribution over the chip area as well. In other words, temperature mapping is required.

Conventionally, the thermal resistance of an LED chip is considered as the parameter independent of the operating current, in a similar way to an electrical resistance. This analogy is correct, however, only in the specific case when the generated heat distribution inside the chip is uniform. More commonly, the increase in the operating current leads to enhanced current crowding, i. e. to the nonuniform distribution of the current density in the active region.

The crowding current around the contact electrode edges involves the localization of the heat generation, thus forming a non-uniform lateral temperature distribution in the chip. As a result, the effective cross-section of the heat flow moving in the direction of a substrate decreases and heat removal deteriorates as compared to one through the uniform generation of heat.

Since local temperature and current density have a significant influence on the local internal quantum efficiency (IQE) of light emission, the 
current spreading over the LED active region and related temperature distribution become the critical factors eventually affecting the overall output characteristics of the light emitters (the optical power and the efficiency). Therefore, the investigation of their non-uniformity over the chip as a function of operating current seems to be especially important for state-ofthe-art high-power LEDs.

In this paper, we consider various experimental and theoretical approaches to evaluating non-uniformity in temperature distribution, current density, and electroluminescence intensity in high-power LEDs and its variation with the LED operating current.

\section{Experimental}

Commercial Luxeon Rebel ES LEDs produced by Philips Lumileds have been the subject of our investigation. The area of the emitting chip was $1340 \times 1340 \mu \mathrm{m}$. This device is known as the thin-film flip-chip InGaN/GaN multiple-quantum-well LED (TFFC LED) [3]. To provide efficient heat removal from the active region, the LED chip is mounted on a ceramic submount with a $p$-layer and then the submount is soldered on a metal-core printed circuit board (MCPCB). The MCPCB is in turn mounted onto an outside bulk radiator. The general view of the LED and the photomicrograph of the operating LED chip are shown in Fig. 1.

\subsection{Transient $p-n$ junction-to-case thermal resistance}

Thermal resistances of individual LED units are conventionally determined similarly to electric resistance, with a thermal flow considered instead of an electric current, and temperature instead of voltage. The heat spreads from the active region through the chip to the ceramic substrate, and then to the MCPCB and the heat sink which are considered as elements of an equivalent heat circuit like the current flow in an equivalent electrical circuit. Such a circuit, within the framework of the Cauer set-up, consists of some resistors and capacitors connected to a common bus (see Fig. 2).

The thermal capacities of the LED distinct layers affect only the transient characteristics of device, namely, heating/cooling rates when turning the device on/off.

In order to determine the thermal resistance with the forward voltage relaxation method, the LED chip is initially driven by a test current of $5 \mathrm{~mA}$. Under this current, the device does not self-heat, and the temperature of the $p-n$ junction depends on the external radiator, varying through a range of $20-100{ }^{\circ} \mathrm{C}$ with an accuracy of $0.5{ }^{\circ} \mathrm{C}$. The forward voltage is recorded as a function of temperature. The linear voltage - temperature dependence with a coefficient of $-1.733 \mathrm{mV} / \mathrm{K}$ was established using these measurements. The obtained value is to be used for determining the $p-n$ junction

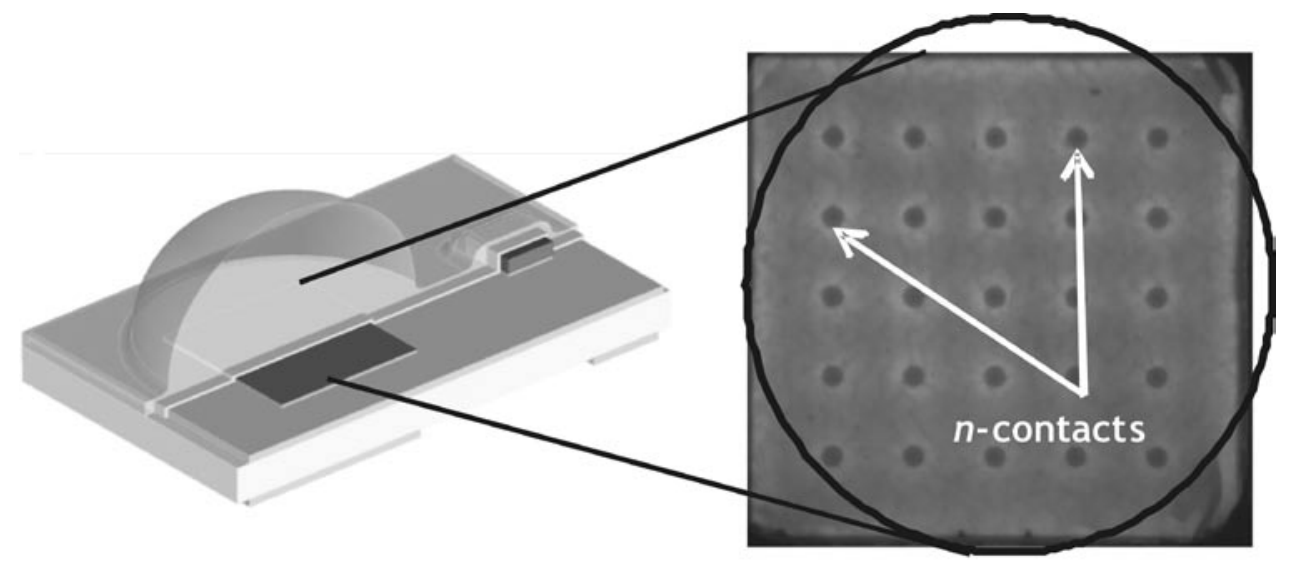

Fig. 1. Schematic general view and photomicrograph of the operating Luxeon Rebel LED; arrows indicate some $n$-contact pads formed onto the $n$-contact layer (opened by etching the LED structure) 


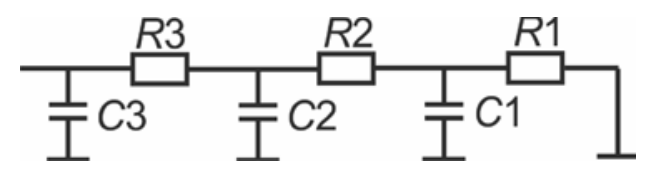

Fig. 2. An example of the Cauer's equivalent circuit used for an analysis of a thermal resistance

temperature under real operating conditions.

Next, the thermal transient characteristics of the LED were measured by step-like quick switching to a high constant driving current. From this moment on, the LED was gradually heated; the heat generated in the chip was partly consumed for heating the LED units (chip, submount, and MCPCB) and partly transferred to the radiator and then to the ambient air. The temperature evolution of the $p-n$ junction during heating was tracked by the changes in forward voltage measured at the moments when short test current pulses were supplied (as described above), with the pulses 'cutting' the direct heating working current with a specific frequency. The subsequent processing analysis of the voltage transient characteristic of the $p-n$ junction using the so-called structure function [4] allowed to calculate the components of the equivalent thermal circuit and the total thermal resistance as well. Plotting the derivative, i.e. the so-called differential structure function, demonstrated clearly the peaks corresponding to the drastic changes in the thermal properties of the LED layers (Fig. 3). These peaks could be attributed to specific unit borders inside the LED (chip, submount, solder joints, etc.), while the distance between the peaks shows the thermal resistances of the respective LED units. The detailed description for the measurement procedure and its analysis may be found in Ref. [5] and references therein.

The above method is implemented in a commercial Thermal Transient Tester T3Ster by MicRed, Ltd. The T3Ster heats the LED with a constant current and uses Cauer's thermal equivalent circuit for data processing.

The differential structure function obtained with the T3Ster at the operating heating currents of 100, 300, 700, and $900 \mathrm{~mA}$ is shown in Fig. 3. The first two peaks attributed to the thermal resistances $(i)$ between the $p-n$ junction and

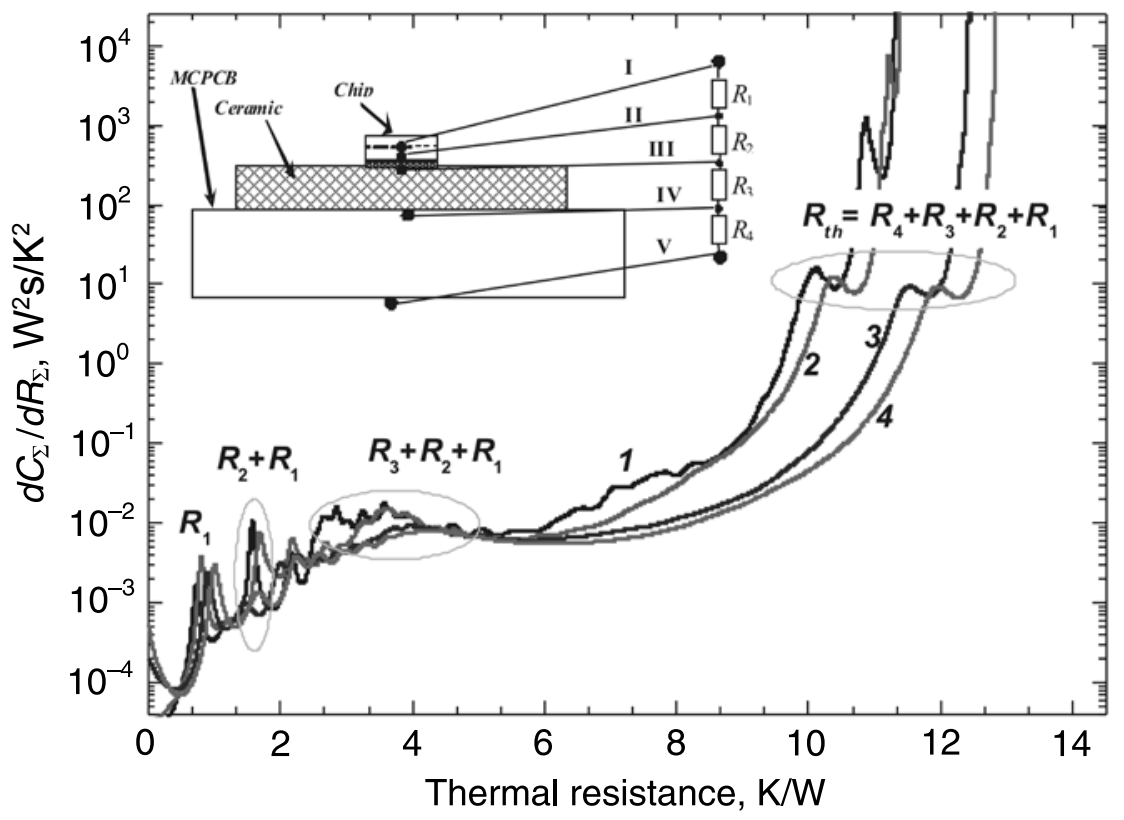

Fig. 3. Differential structure functions obtained with the T3Ster for different currents, mA: $100(1), 300(2), 700(3), 900(4)$.

Peaks in the curves $1-4$ correspond to the thermal resistances and their sums; chip design and corresponding thermal resistances are shown schematically in the inset; temperature points included: at the $p-n$ junction (I), die (II), die - ceramic submount interface (III), solder joint (IV), bottom (V) 


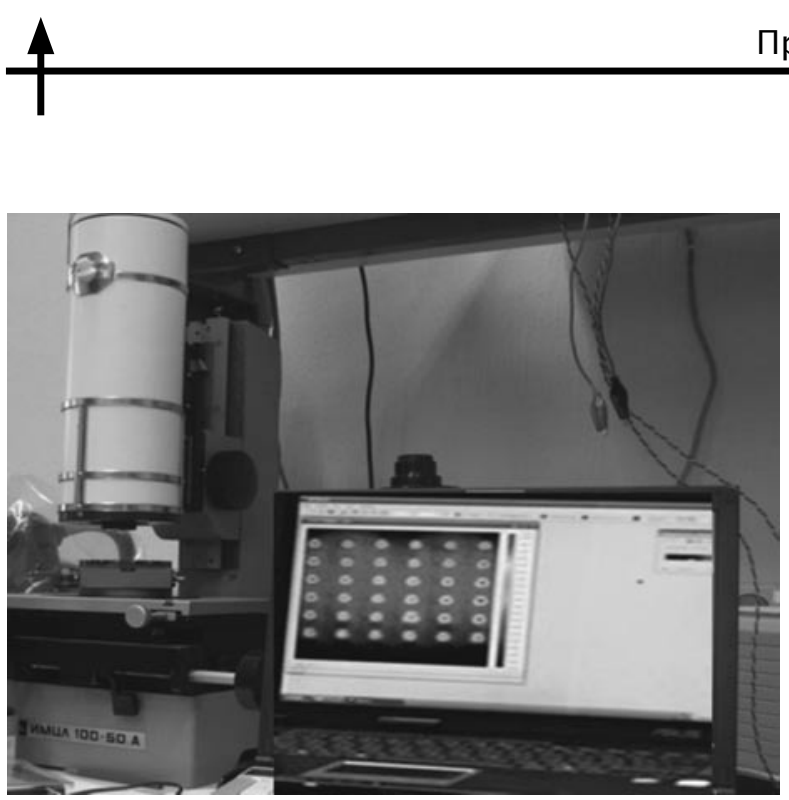

Fig. 4. General view of the UTK 1 IR microscope with the interface

the chip rear surface and (ii) between the chip surface and the submount are, apparently, nearly the same for all the heating currents. The third peak associated with the thermal resistance of the submount becomes shifted to higher values as the current is increased, which indicates the growth of the respective thermal resistance with current. The increase of the total thermal resistance is also clearly seen from the shift of the last peak. The thermal resistance value provided by the MCPCB is estimated from the plot at $7 \mathrm{~K} / \mathrm{W}$, so it is a primary contributor compared with the rest of the LED units. The total thermal resistance is found to increase by $\sim 20 \%$, from 10 to $12 \mathrm{~K} / \mathrm{W}$, under an increase of the operating current from 100 to $900 \mathrm{~mA}$.

The T3Ster equipment is basically applicable to any semiconductor device, not only LED; therefore, its data processing implies the conversion of the total supplied electric power into heat. In LEDs, however, much of the electric power is converted into light and is therefore not involved in the device heating. For consistency, all the results in this paper do not take the power emission (optical cooling) into account. Otherwise the actual thermal resistance of the chip would increase by a factor of $\left(1-\eta_{W}\right)^{-1}$, where $\eta_{W}$ is the LED wall plug efficiency nearly equal to $30 \%$.

\subsection{Infrared thermal microscopy mapping the LED}

An alternative approach to determining the chip surface temperature distribution is based on the application of thermal imaging equipment. This allows to measure the temperature directly and thus obtain more detailed information on the temperature distribution over the surface.

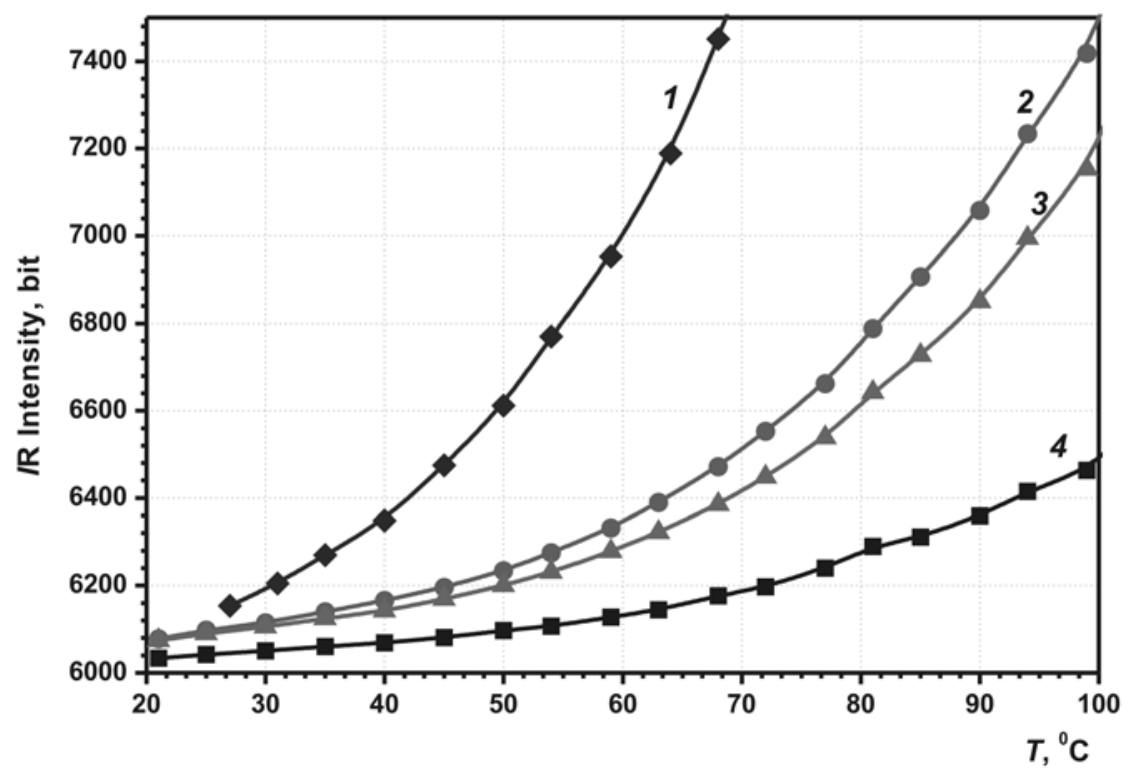

Fig. 5. Plots of IR emission intensity versus temperature for various materials included in the LED design: InAs as a black-body imitator (1), $\mathrm{Ti} / \mathrm{Ag}$ as an $n$-contact (2), Ni/Ag as a $p$-contact (3), $\mathrm{Au}(4)$ 
There exists a wide diversity of IR thermal imaging systems, e. g., the one manufactured by Cedip Infrared Systems, intended for evaluating the temperature of objects on the basis of their intrinsic thermal radiation in the spectral range from 3 to $12 \mu \mathrm{m}$. However, these systems are mostly applicable to macroscopic objects. In the present study, we employed a UTK1 infrared (IR) microscope developed at the Institute of Semiconductor Physics, Siberian Branch of Russian Academy of Sciences, for analyzing the temperature distributions in LED chips with a spatial resolution of several micrometers (see Fig. 4 [6]).

The thermal emission was recorded with an InAs charge injection device, a photo detector array $(128 \times 128$ elements with a $50 \mu \mathrm{m}$ step between them) and spectral sensitivity range of 2.5-3.1 $\mu \mathrm{m}$ (near IR). The image field of the microscope was $400 \times 400 \mu \mathrm{m}(\sim 3 \mu \mathrm{m}$ per element).

One of the main methodological problems encountered when using the thermal imaging microscopy for temperature analysis in AlInGaN LEDs is the transparency of the epitaxial structure itself and of the sapphire substrate in the operating IR spectral range and a great spread in the emissivity values for various materials involved in the device: contact electrodes, reflecting and antireflecting coatings, substrates, phosphor, etc. [7]. Therefore, the initial calibration is of great importance; using it, a)

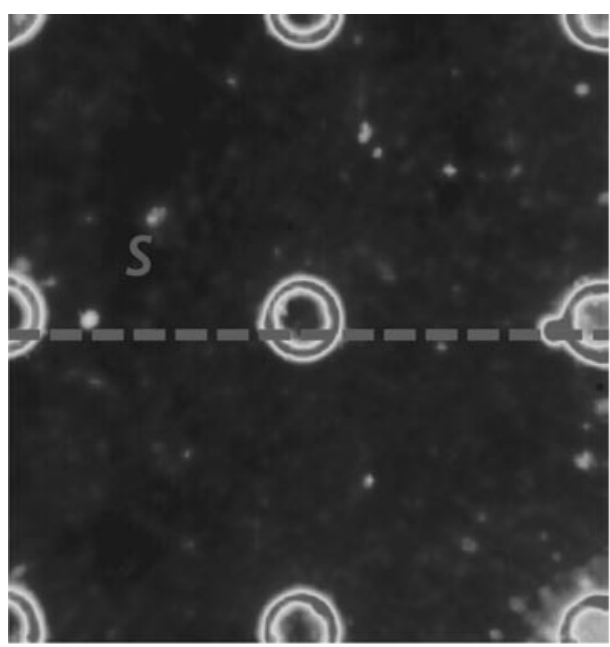

b)

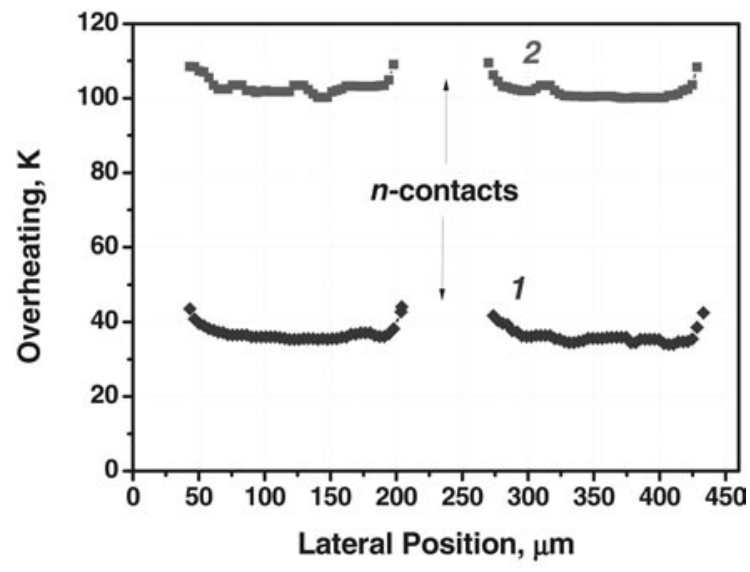

c)

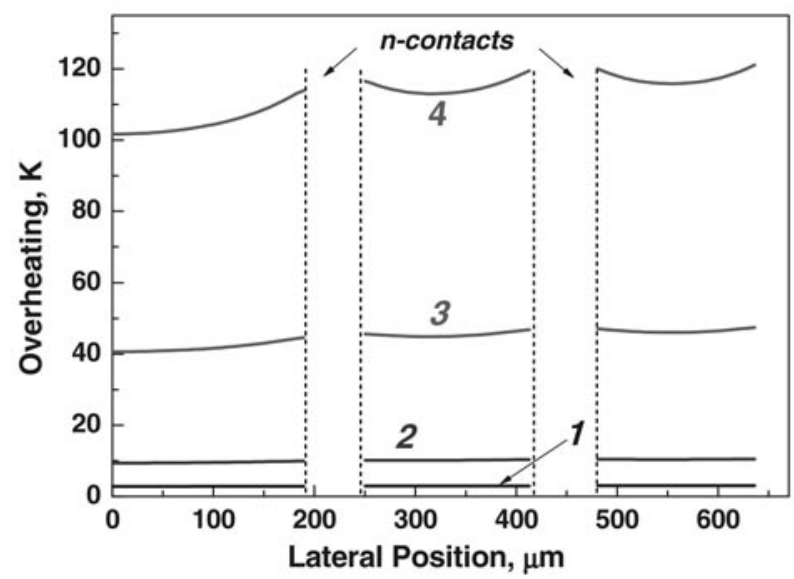

Fig. 6. Results of IR mapping the LED: $a-2 \mathrm{D}$ near-field IR intensity distribution measured at a current of 2A (only a quarter of the chip area is displayed); $b$ - experimental local heating profile over the cross-section $S$ (measured at currents of $1 \mathrm{~A}(1)$ and $2 \mathrm{~A}(2)) ; c-$ simulated local heating profiles in the cross-section $S$ (taken currents of $0.1 \mathrm{~A}(3), 0.3 \mathrm{~A}(4), 1.0 \mathrm{~A}(1)$, and $2 \mathrm{~A}(2)$ ) 
the temperature of objects (all LED structural units) is maintained by an external heater with simultaneous digital recording of the IR emission intensity (bits). The 'emission intensitytemperature' calibration curve is then used to determine the absolute temperatures of the objects in real operation mode of the LED. Fig. 5 shows some examples of calibration curves for materials used in the LED design and for InAs substrate with anti-reflecting coating serving as a blackbody imitator. As expected, minimum emissivity is observed for the highly reflecting copper and gold films deposited by thermal evaporation in vacuum. With this calibration method, the absolute temperature is in error by no more than $\sim 2 \mathrm{~K}$ (at low temperature and low material emissivity).

a)

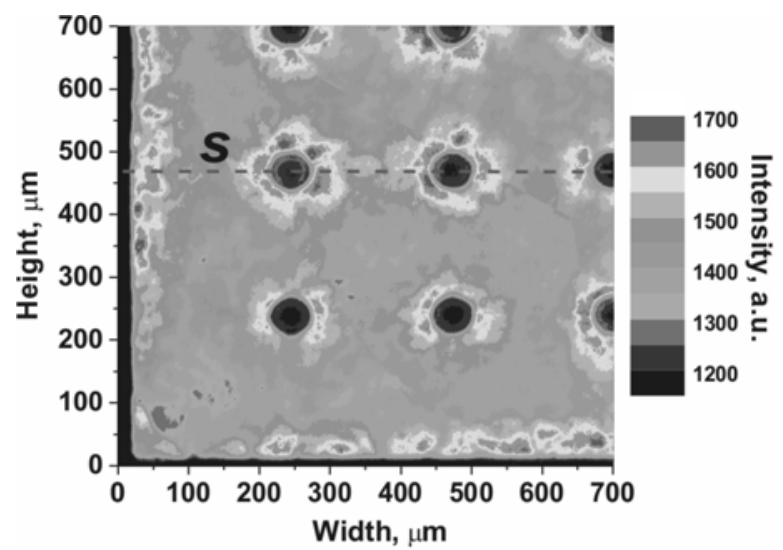

Fig. 6, $a$ shows a picture of a part of the LED chip operating at the current of $2 \mathrm{~A}$, the picture being recorded with an IR microscope and processed with the included software. The corresponding temperature distributions in section $S$, i. e. the local temperature profile in the LED chip, are plotted in Fig. $6, b$ for two selected values of the operating current.

On one hand, at both current values, the temperature distributions remain nearly uniform, indicating a good lateral heat spread inside the upper layer of the LED chip. On the other hand, there is a tendency towards a concavity of temperature distribution profile. This fact may be interpreted as a fingerprint of current crowding in the LED dice providing a higher current density next to the electrode

b)

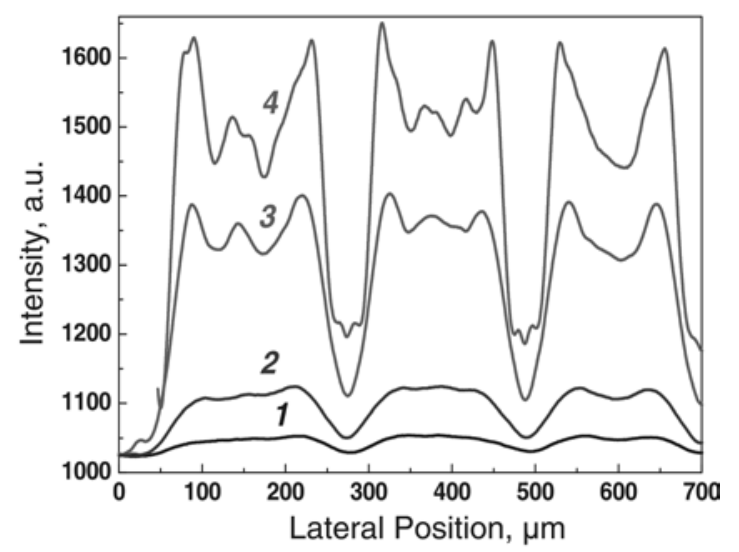

c)

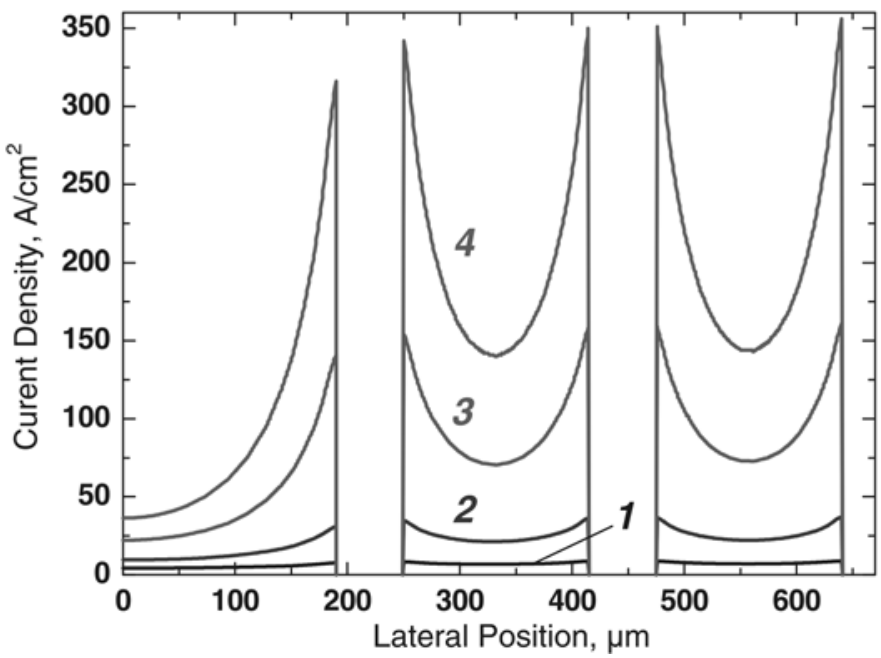

Fig. 7. Experimental 2D $(a)$ and 1D $(b)$ near-field EL intensity distributions and simulated 1D lateral distribution of the vertical current density $(c)$.

The chip part and the cross-section $S$ are identical to those of given in Fig. 6. The driving currents are as follows: $0.1 \mathrm{~A}(1), 0.3 \mathrm{~A}(2), 1.0 \mathrm{~A} \mathrm{(3)}$, and $2.0 \mathrm{~A}(4)$ 
edges, thus increasing the local temperature in the LED.

\subsection{The near-field electroluminescence imaging by means of optical microscopy}

In order to qualitatively assess the current spreading in the LED die, the near-field distribution of electroluminescence (EL) intensity was monitored over the blue-green spectral range by means of a Mitutoyo optical microscope and a Canon EOS 5D camera with a $12 \mathrm{Mpx}$ matrix. The distribution obtained at a driving current of $2 \mathrm{~A}$ is shown in Fig. 7, $a$. The observed increase of the emission intensity next to the $n$-electrode edges is an indirect evidence for considerable current crowding. The evolution of the EL intensity distribution in the cross-section $S$ with the driving current varying in the range of $0.1-2.0 \mathrm{~A}$ is shown in Fig. 7, $b$. It demonstrates clearly that the concavity of the EL profile becomes more pronounced at high driving currents.

It should be emphasized that the observed EL intensity non-uniformity cannot serve as a measure of the current density non-uniformity in the emitting chip, as it is often assumed. The EL non-uniformity is always more smoothed than the current density one due to photon propagation and their multiple reflections and scattering inside the LED chip. Therefore, to find a correlation between the current density and the EL intensity distribution in a LED chip, numerical simulations are of major importance.

\section{Simulation}

To interpret the experimental results, we carried out coupled hybrid 1D/3D simulations of the current spreading in the LED chip and heat transfer in the LED chip and the submount [8]. The active area was regarded as a thin layer with the Shockley dependence of the local current density $j_{p-n}$ on the local applied $p-n$ junction bias voltage $U_{p-n}$ :

$$
j_{p-n}=j_{s}(T) \cdot\left[\exp \left(U_{p-n} / m k T\right)-1\right],
$$

where $m$ is the ideality factor, and the saturation current $j_{s}$ is assumed to increase exponentially with temperature:

$$
j_{s}(T)=j_{0} \exp (-\hbar \omega / k T) .
$$

Here $\hbar \omega$ is a mean energy of emitted photons; $j_{0}$ is a fitting parameter for the magnitude of the saturation current which was adjusted to fit experimental turn-on voltage value. The internal quantum efficiency $(\eta)$ dependence on the current density was approximated by the ABC-model:

$$
\begin{gathered}
j_{p-n}=q d\left(A n+B n^{2}+C n^{3}\right), \\
\eta_{i}=\frac{B n}{A+B n+C n^{2}},
\end{gathered}
$$

with the recombination constants $A=1 \cdot 10^{7}$ $\mathrm{s}^{-1}, B=2 \cdot 10^{-11} \mathrm{~cm}^{3} / \mathrm{s}$, and $C=3 \cdot 10^{-30} \mathrm{~cm}^{6} / \mathrm{s}$. Here $n$ is a concentration of electron-hole pairs injected into the LED active region; $d$ is an effective thickness of the total active region; $q$ - electron charge.

The coupled problem of the current spreading and heat transfer in the LED chip was solved numerically using the commercial SimuLED software package [9].

The sheet resistance of the $n$-GaN contact layer being equal to $22 \Omega / \mathrm{cm}^{2}$, and the specific resistance of the contact formed to $p-\mathrm{GaN}$ being equal to $10^{-3} \Omega \cdot \mathrm{cm}^{2}$, were chosen, respectively, as the input parameters.

In carrying out the simulation, we assumed the heat to be released through the bottom surface of the submount where the boundary conditions of the third kind for the heat flux were fulfilled. The heat-transfer coefficient was chosen to be $5 \cdot 10^{4} \mathrm{~W} /\left(\mathrm{m}^{2} \cdot \mathrm{K}\right)$ fitting the overall thermal resistance to the measured value. The submount thermal conductivity was assumed to be of $50 \mathrm{~W} /(\mathrm{m} \cdot \mathrm{K})$. The thermal resistance was calculated as a ratio of the average overheating of the active region to the total electric power supplied to LED, in order to keep consistence with our experimental data. It is worthy to note that the computations should include the ceramic submount to enable lateral heat transfer. It is important for the correct prediction of the lateral temperature distribution, as the bulk submount provides more intensive lateral heat transfer than the chip with removed sapphire substrate, the chip thickness being only $\sim(3-5) \mu \mathrm{m}$ after this removal.

The computed active region overheating and current density profiles in the cross-section $S$ simulated for various driving currents are 
plotted in Figs. $6 c$ and $7 c$, respectively. These figures show the lateral current density nonuniformity to increase dramatically with current. At the driving currents of $700 \mathrm{~mA}$ and higher, the maximum current density at the mesa edge is more than two times higher than the typical current density between the mesas. The current density next to the external chip boundary is even lower.

As a rule, the heat generation rate in the active region is roughly proportional to the current density with some deviation from the linearity coming from the lateral variation of the internal quantum efficiency $\eta_{i}$ and $U_{p-n}$. Nevertheless, the lateral distribution of the overheating is predicted to be much more uniform than that of the current density. Simulation shows that the lateral temperature variation does not exceed $\sim 20 \%$ of the mean overheating at the driving current as high as $2 \mathrm{~A}$. This latter fact is attributed to intensive lateral heat transfer in the ceramic submount, indicating that its thermal properties are essential for the overall thermal management of the LED chip.

\section{Summary}

The paper is focused on the experimental and simulation approaches to evaluating the thermal resistance and non-uniformity of current density, electroluminescence intensity and temperature distribution in the high-power flip-chip AlInGaN LEDs.

The total thermal resistance of the LED and its components were determined from the measurements of transient temperature-sensitive characteristics (forward voltage $U_{p-n}$ ) of the chip under a step-like drive of heating current. The total thermal resistance of the LED is found to grow by about $20 \%$ from 10 to $12 \mathrm{~K} / \mathrm{W}$ while the driving current is increased from zero to $1 \mathrm{~A}$. The variation of the thermal resistance is attributed to the effect of current crowding near the $n$-electrode edges with corresponding localization of heat generation and relevant reduction of the effective area of intensive heat release from the chip into submount.

This conclusion is supported by direct measurements of the temperature distribution and near-field EL intensity using IR and optical microscopy. The experimental results are in good agreement with the numerical simulation of the temperature and current density distributions in the AlInGaN flip-chip LED.

The results obtained prove that it is important to take into account the thermal properties of all the chip units, both to reduce the total thermal resistance of the chip and to attain more uniform temperature distribution in the LED active region. In modern practice, a proper thermal management in high-power LED chips is a critical factor in improving all LED parameters.

This investigation was financially supported by Ministry of Education and Science of Russian Federation (grant: 14.607.21.0010 of 05.06.2014, unique ID: RFMEFI60714X0010).

\section{REFERENCES}

[1] C.A. Hurni, A. David, M.J. Cich, et al., Bulk GaN flip-chip violet light-emitting diodes with optimized efficiency for high-power operation, Applied Physics Letters 106(2015) 031101.

[2] J. Carey, New LED architectures and phosphor technologies lower costs and boost quality, LEDs Magazine, 72 (2014) 67-71.

[3] O.B. Shchekin, J.E. Epler, T.A. Trottier, et al., High performance thin-film flip-chip InGaN-GaN light-emitting diodes, Applied Physics Letters 89 (2006) 071109.

[4] V. Szekely, A new evaluation method of thermal transient measurement results, Microelectronics journal, 28 (1997) 277-292.

[5] A. Poppe, Thermal Characterization Confirms Real-World LED Performance.URL: http:// s3.mentor.com/public_documents/whitepaper/ resources/ mentorpaper_59097.pdf
[6] V.M. Bazovkin, A.A. Guzev, A.P. Kovchavtsev, et al., Teplovizionnyi mikroskop, Prikl. Fiz. 2 (2005) 97-102.

[7] A.L. Zakgeim, G.L. Kuryshev, M.N. Mizerov, et al., Issledovanie teplovych protsessov $\mathrm{v}$ mosh'nych InGaN/GaN flip-chip svetodiodach s ispol'zovaniem infrakrasnoi teplovizionnoi mikroskopii. Fizika i Tekhnika Poluprovodnikov, 44 (3) (2010) 390-396.

[8] M.V. Bogdanov, K.A. Bulashevich, I.Y. Evstratov, et al., Coupled modeling of current spreading, thermal effects and light extraction in III-nitride light-emitting diodes, Semiconductor Science and Technology, 23(12) (2008) $10-16$.

[9] SimuLED - engineering tool for LED and laser diode design and optimization. URL: http:// www.str-soft.com/products/SimuLED/index.htm. 


\section{THE AUTHORS}

ALADOV Andrei V.

Submicron Heterostructures for Microelectronics Research and Engineering Center of the RAS.

26 Politekhnicheskaya St., St. Petersburg, 194021, Russian Federation

aaladov@mail.ioffe.ru

BULASHEVICH Kirill A.

STR Group - Soft-Impact, LTD.

P.O. Box 33, 27 Engels av., St. Petersburg, 194156, Russian Federation

kirill.bulashevich@str-soft.com

\section{CHERNYAKOV Anton E.}

Submicron Heterostructures for Microelectronics Research and Engineering Center of the RAS.

26 Politekhnicheskaya St., St. Petersburg, 194021, Russian Federation

chernyakov@mail.ioffe.ru

KARPOV Sergey Yu.

STR Group - Soft-Impact, LTD.

P.O. Box 33, 27 Engels av., St. Petersburg, 194156, Russian Federation

sergey.karpov@str-soft.com

\section{VALYUKHOV Vladimir P.}

Peter the Great St. Petersburg Polytechnic University

29 Politekhnicheskaya St., St. Petersburg, 195251, Russian Federation

Valyukhov@yandex.ru

ZAKGEIM Alexander L.

Submicron Heterostructures for Microelectronics Research and Engineering Center of the RAS 26 Politekhnicheskaya St., St. Petersburg, 194021, Russian Federation

zakgeim@mail.ioffe.ru

Аладов А.В., Булашебич К.А., Черняков А.Е., Карпов С.Ю., Валюхов В.П., ЗакгеЙМ А.Л. ТЕПЛОВОЕ СОПРОТИВЛЕНИЕ И НЕОДНОРОДНОСТЬ РАСПРЕДЕЛЕНИЯ ЭЛЕКТРОЛЮМИНЕСЦЕНЦИИ И ТЕМПЕРАТУРЫ В МОЩНЫХ AIGalnNСВЕТОДИОДАХ.

Теоретически и экспериментально исследованы распределения светового излучения, тока и тепла, а также их влияние на общее тепловое сопротивление в мощных AlGaInN светодиодах флип-чип конструкции. Тепловое сопротивление измерялось как по методу релаксации прямого напряжения с использованием прибора T3Ster, так и с применением инфракрасной тепловизионной микроскопии. Ближнее поле собственной электролюминесценции регистрировалось с помощью оптического микроскопа и цифровой фотокамеры, температурный мэппинг осуществлялся с помощью инфракрасного микроскопа высокого разрешения. Для интерпретации экспериментальных результатов проводилось трехмерное численное моделирование растекания тока и теплообмена в светодиодном кристалле с помощью программного пакета SimuLED. Получено хорошее согласие экспериментальных и расчетных данных, обнаружен рост теплового сопротивления с увеличением тока, обусловленный эффектом локализации тока вблизи контактных площадок.

СВЕТОДИОД, ТЕПЛОВОЕ СОПРОТИВЛЕНИЕ, ТОКОРАСТЕКАНИЕ, ИНФРАКРАСНАЯ ТЕПЛОВИЗИОННАЯ МИКРОСКОПИЯ, ЭЛЕКТРОЛЮМИНЕСЦЕНЦИЯ.

\section{СПИСОК ЛИТЕРАТУРЫ}

[1] Hurni C.A., David A., Cich M.J., et al. Bulk GaN flip-chip violet light-emitting diodes with op- timized efficiency for high-power operation// Applied Physics Letters. 2015. Vol. 106. P. 031101. 
[2] Carey J. New LED architectures and phosphor technologies lower costs and boost quality// LEDs Magazin. 2014. Vol. 72, September. Pp. 67-71.

[3] Shchekin O.B., Epler J.E., Trottier T.A., et al. High performance thin-film flip-chip InGaNGaN light-emitting diodes// Applied Physics Letters. 2006. Vol. 89. P. 071109.

[4] Szekely V. A new evaluation method of thermal transient measurement results // Microelectronic Journal. 1997. Vol. 28. Pp. 277-292.

[5] Poppe A. Thermal Characterization Confirms Real-World LED Performance.URL: http:// s3.mentor.com/public_documents/whitepaper/ resources/ mentorpaper_59097.pdf

[6] Базовкин В.М.М., Гусев А.А., Ковчавцев А.П. и др. Тепловизионный микроскоп// При- кладная физика. 2005. Т. 2. С. 97-102.

[7] Закгейм А.Л., Мизеров М.Н., Половинкин В.Г. и др. Исследование тепловых процессов в мощных InGaN/GaN флип-чип светодиодах с использованием инфракрасной тепловизионной микроскопии// Физика и техника полупроводников. 2010. Т. 44, Вып. 3.

C. $390-396$.

[8] Bogdanov M.V., Bulashevich K.A., Evstratov I.Y., et al. Coupled modeling of current spreading, thermal effects and light extraction in III-nitride light-emitting diodes// Semiconductor Science and Technology. 2008. Vol. 23. No. 12. Pp. 10-12.

[9] SimuLED - engineering tool for LED and laser diode design and optimization URL: http:// www.str-soft.com/products/SimuLED/index.htm.

\section{СВЕДЕНИЯ ОБ АВТОРАХ}

АЛАДОВ Андрей Вальменович - старший научный сотрудник Научно-технологического центра микроэлектроники и субмикронных гетероструктур РАН.

194021, Российская Федерация, г. Санкт-Петербург, Политехническая ул., 26

aaladov@mail.ioffe.ru

БУЛАШЕВИЧ Кирилл Александрович - научный сотрудник ООО «Софm-Импакт», 194156, Российская Федерация, г. Санкт-Петербург, а/я 83, пр. Энгельса, 27

kirill.bulashevich@str-soft.com

ЧЕРНЯКОВ Антон Евгеньевич - кандидат физико-математических наук, научный сотрудник Научно-технологического центра микроэлектроники и субмикронных гетероструктур РАН.

194021, Российская Федерация, г. Санкт-Петербург, Политехническая ул., 26

chernyakov@mail.ioffe.ru

КАРПОВ Сергей Юрьевич - кандидат физико-математических наук, ведущий научный сотрудник ООО «Софт-Импакт»,

194156, Российская Федерация, г. Санкт-Петербург, пр. Энгельса, 27

sergey.karpov@str-soft.com

ВАЛЮХОВ Владимир Петрович - доктор технических наук, профессор кафедры радиофизики Санкт-Петербургского политехнического университета Петра Великого.

195251, Российская Федерация, г. Санкт-Петербург, Политехническая ул., 29

Valyukhov@yandex.ru

ЗАКГЕЙМ Александр Львович - кандидат технических наук, заместитель директора по научной работе Научно-технологического центра микроэлектроники и субмикронных гетероструктур РАН.

194021, Российская Федерация, г. Санкт-Петербург, Политехническая ул., 26

zakgeim@mail.ioffe.ru 